Consumer Sophistication and the Role of Emotion on Satisfaction Judgments within Credence Services

\author{
Tony Garry \\ De Montfort University \\ Contact Address \\ Department of Marketing \\ Leicester Business School \\ De Montfort University \\ The Gateway \\ Leicester LE1 9BH \\ Tel: 01162577226 \\ Fax: 01162506136 \\ Email:tgmar@dmu.ac.uk
}




\title{
Consumer Sophistication and the Role of Emotion on Satisfaction Judgments within Credence Services
}

\begin{abstract}
Evidence which demonstrates a link between the affective dimension and satisfaction in a tangible product based context is well documented. However, when placed in a credence service context the role of Affect becomes more complex. Previous research in this field has assumed consumer homogeneity when there is increasing evidence of consumer heterogeneity. This research attempts to address this by examining affective reactions to service encounters among two groups of respondents, one with the ability to make performance assessments about the service and one without. Findings suggest consumers of differing sophistication will vary in the way they form expectation and performance assessments about the technical, functional and affective components of credence services and that consumer sophistication may have a moderating influence on affective reactions evoked. This in turn has implications for the design and delivery of service offerings within such contexts.
\end{abstract}




\section{Consumer Sophistication and the Role of Emotion on Satisfaction Judgments within Credence Services}

\section{INTRODUCTION}

Evidence that demonstrates the link between the affective dimension and satisfaction in a tangible product based context is well documented (e.g. Westbrook, 1987; Oliver, 1993). However, when placed in a credence service context the role of Affect becomes more complex. In such circumstances, other aspects of the service may take on a higher degree of significance (e.g. Crosby and Stevens, 1987). In particular, there is evidence to suggest that consumers will, in part, rely on their affective reaction to the service (e.g. White and Yu, 2005) and service provider (Alford and Sherrell, 1996).

However, consumer homogeneity has largely been assumed and research has largely ignored the concept of 'consumer sophistication' (e.g. Smith and Bolton, 2002). More specifically, previous research has assumed consumers either have the ability to form expectation and performance assessments about the service or product (e.g. Oliver, 1993) or, as typically associated with credence service markets, they do not (e.g. Alford and Sherrell, 1996). Consequently, this paper reports on a study which aims to:

- Explore the contribution of emotion on the formulation of satisfaction judgments within credence services and;

- Examine how this may vary according to the sophistication of the consumer and their ability to form expectation and performance assessments 
The paper is structured as follows. First, there is a brief synopsis of the recent literature on emotion and consumption satisfaction and research propositions are developed consistent with the research aims. The research design is then described and the results discussed. The paper concludes with implications and recommendations for future research.

\section{LITERATURE REVIEW}

On reviewing the literature, there is little consistency in the use of terminology related to Affect and its interchangeability with emotion (Bagozzi et al, 1999). It is therefore important to define the meaning of the terms for the purpose of this paper. Bagozzi et al (1999) define Affect as " an umbrella for a set of more specific mental processes including emotions, moods and possible attitudes" [p.184]. This suggests Affect is a more generalised feeling or state where as emotion is "a mental state with a specific referent" and is therefore evoked by "a specific target such as a person, object or event" (Johnson and Stewart, 2006: p.5).

To understand how emotion relates to consumption satisfaction, it is necessary to review the literature involving measures of both so that the relationship between them can be assessed (Oliver, 1997). In an early study by Westbrook (1987), positive affective elements (interest, excitement, happiness and joy) and some negative affective elements (fear, terror, contempt, scorn, shame, shyness, guilt and remorse) based on Izard's (1972) Differentiated Emotional Scale (DES) were related to a number of consumer satisfaction 
measures. Using the product categories of automobiles and Cable TV, Westbrook (1987) was able to demonstrate:

- that positive and negative Affect represented relatively independent dimensions of affective response to products

- that positive and negative Affect were not mutually exclusive and;

- that the reports of positive and negative Affect related directly to product satisfaction judgments.

A subsequent study by Mano and Oliver (1993) examined a full circumplex of emotions along with measures of utilitarian and hedonistic values across a range of products. Their findings supported the Affect circumplex within the context of consumption satisfaction and also suggested a joint operation of product influences and Affect on satisfaction.

This research was further augmented by Oliver (1993) in a later study examining satisfaction influences for a product (automobiles) and a service (a university course). This study differed from the previous one insofar as actual attributes were examined and not general descriptions of functional or hedonic values (e.g. instructor, work load, evaluation etc.) . Oliver's results suggest that product attribute satisfactions and dissatisfactions are the source of Affect and that Affect may partially mediate product attribution influences on overall satisfaction. This is represented conceptually in Figure 1. 


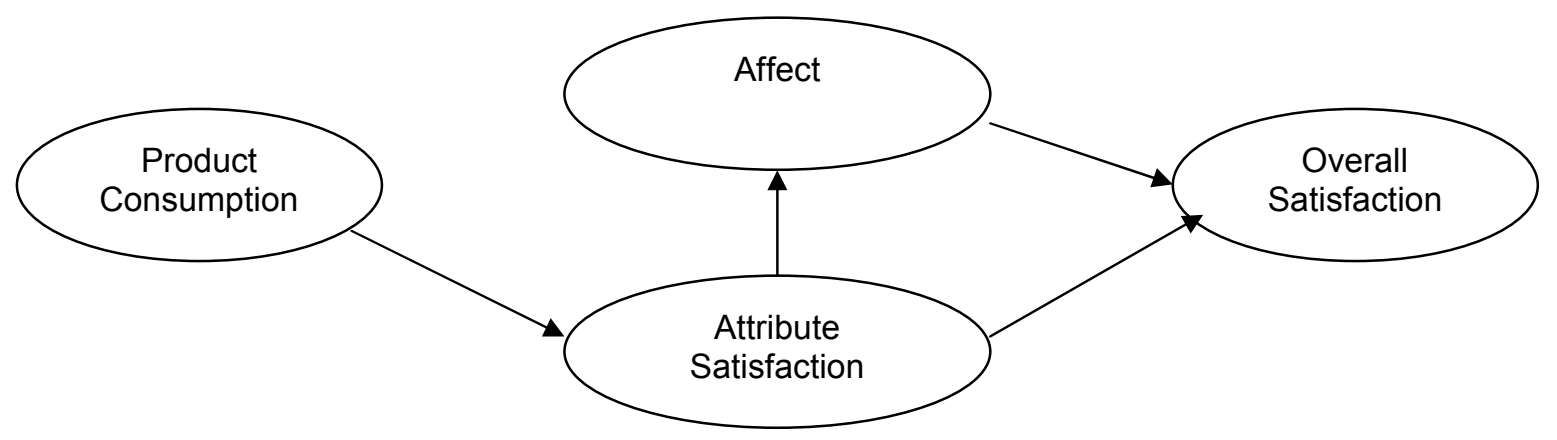

Figure 1: The Attribute based Satisfaction Model (Based on Oliver's Research, 1993)

However, the research findings reviewed so far have primarily been in tangible, productbased contexts.

When placed in a service context, they may have deficiencies. More specifically;

- there is no provision for consumer reactions to the service provider (Alford and Sherrell, 1996).

- consumer sophistication is assumed insofar as the ability to form expectation and performance assessments about the attributes of the core product by the consumer is a premise of the research (Alford and Sherrell, 1996).

Credence services in particular may not provide such opportunities. Within such contexts, other aspects of the service may take on a higher degree of prominence when making satisfaction judgments (e.g. Crosby and Stevens, 1987).

In an attempt to address these deficiencies, Alford and Sherrell (1996) investigated the role of Affect in evaluating satisfaction within a credence service context. In such circumstances, Alford and Sherrell's results suggest that consumers will use two sources 
of information to evaluate service attributes and derive satisfaction judgments. Firstly, intuitive logic and the consistency with which the service process is performed (i.e. the functional attributes) and secondly, the customers' affective reaction to the service provider. This is represented conceptually in Figure 2. Alford and Sherrell's (1996) results are substantiated by more recent studies which simultaneously confirm the existence and assess the impact of cognitive and affective components on satisfaction judgments (e.g. Homburg et al, 2006).

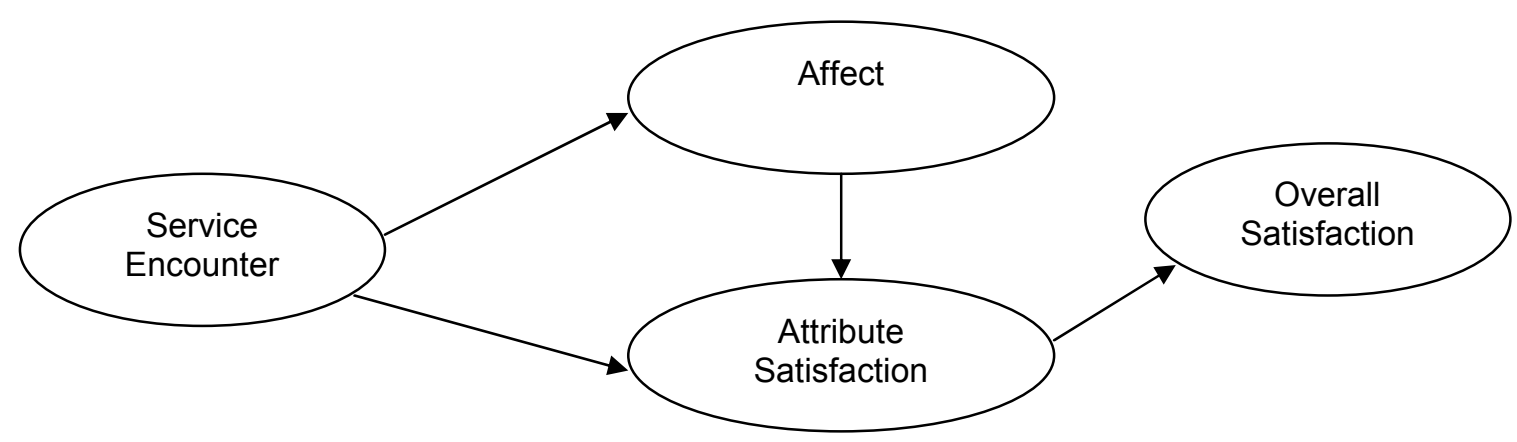

Figure 2: The Affect based Service Satisfaction Model (Based on Alford and Sherrell's Research, 1996)

However, with all these studies consumer homogeneity has been assumed when there is increasing evidence to suggest consumer heterogeneity exists within such contexts (e.g. Hanlon, 1997). More precisely, consumers may in varying degrees, possess pertinent skills, knowledge, experience and possible elements of technical expertise that enable them to form expectation and performance assessments about the service they are receiving. 


\section{Development of Propositions}

The purpose of the current research is to examine how the degree of consumer sophistication may affect the priority accorded to the affective, technical and functional elements of the service, the nature of their evaluation and lastly the functionality accorded to them. More specifically, it is proposed that where the consumer is able to form expectation and performance assessments about the attributes of the core service, satisfaction with these will be the main contributor towards overall satisfaction judgments (e.g. Oliver, 1993). Thus;

Proposition 1: Where there is a higher level of consumer sophistication, there will be a higher reliance on evaluation of the technical attributes of the service rather than the emotional or functional attributes when deriving overall satisfaction judgments.

Where the consumer is unable to form expectation and performance assessments about the attributes of the core service, overall satisfaction judgments will be derived from two sources. Satisfaction with the functional attributes of the service (e.g. Crosby and Stevens, 1987) and the consumer's emotional reaction to the service provider (Alford and Sherrell, 1996). Thus;

Proposition 2: Where there is a lower level of consumer sophistication, there will be a higher reliance on evaluation of the functional and emotional attributes of the service rather than the technical attributes when deriving overall satisfaction judgments

\section{METHODOLOGY}

In order to investigate these propositions, a two-stage methodology was adopted incorporating exploratory interviews and scenario testing. 


\section{Stage One: Exploratory Interviews}

This stage of the research was primarily exploratory. A qualitative approach was judged to be appropriate at this stage as it accommodates 'deep' and 'rich' insights (Geertz, 1973), provides a foundation for theory development (Van Maanen, 1979) and is useful for examining developing social processes (Hartley, 1994). To this end, exploratory interviews were conducted within the context of legal services. On the demand side, a number of interviews were conducted with individuals engaged in the use of legal services. These interviews consisted of private individuals, in-house lawyers and ownermanagers of small and medium sized enterprises (SMEs). On the supply side, interviewees consisted of practice lawyers working for a range of local and national law firms. In all, a total of fourteen interviews were conducted to ensure an appropriate spread of consumer sophistication. The findings of these interviews confirmed that:

- there are varying degrees of consumer sophistication in terms of their ability;

-to issue advice and instructions to the service provider,

-to understand the features and benefits of the service they are receiving and

-to gauge the technical attributes of the service.

- the role accorded to the technical, functional and affective elements of the service may vary according to the level of consumer sophistication.

\section{Stage Two: Scenario Testing}

These results were investigated further using a $2 \times 2 \times 2$ experimental design consisting of scenarios (Randall and Gibson, 1990). Experimentally generated scenario testing has been used widely in a number of research contexts including jury decision making 
(Landy and Aronson, 1969), social status perception (Nosanchuk, 1972), social attitudes (Burstin et al, 1980) and more recently in a marketing context (e.g. Schoefer and Ennew, 2005). This approach may be justified for this research on the basis that:

- it is primarily explorative (Bryman,1989)

- the technique allows for a systematic investigation of a more representative and inclusive set of service encounters than would be possible with a retrospective survey approach

- critically, it allows for the possibility of a clear differentiation between sophisticated and non-sophisticated consumers (Webber, 1992).

The scenarios described a service encounter between a client and a solicitor in a local law firm. The scenarios were manipulated to produce positive and negative outcomes in terms of the technical, functional and emotional elements of the service encounter described in the scenarios (see appendix 1).

The convenience sample consisted of postgraduate students studying on a part-time basis for a range of professional qualifications. Fifty-four responses were from students studying for the Postgraduate Legal Practice Certificate (LPC) and therefore judged to have a higher than average knowledge of the law. Sixty-four of the responses were from students studying for other Postgraduate, business related qualifications and therefore deemed to have an average knowledge of the law (NLPC). 
Particular care was taken with the construction of the technical element of the service encounter to ensure that the legal advice proffered by the solicitor in the scenario revolved around a case in law that the LPC respondents should recognize as being correct or incorrect. Subjects were randomly assigned the scenarios and were asked to read the scenario and complete the attached questionnaire.

The draft questionnaire comprised five sections. The first section consisted of a question designed to evaluate the respondents' perceived realism of the scenarios and their ability to form performance assessments about the service. Initially, respondents were asked to respond to the item "I believe that such an incident can happen in real life" by using a 5point Likert scale (5= "Agree strongly" and 1= "Disagree strongly").

Respondents were subsequently asked to respond to the item "Was the legal advice given correct?" (Yes, No and Don't Know). As part of the focus of this study is a comparison between consumers with differing ability to form expectation and performance assessments about the attributes of the technical and functional dimensions of the service encounter, it was deemed appropriate to ascertain whether respondents could recognize the legal advice offered by the solicitor as being correct or incorrect.

The second section of the questionnaire contained a number of scale items used to measure satisfaction relating to the cognitive element of the service. This was measured using a 5 point Likert scale and asked respondents "How would you rate your satisfaction with the following" (1= "Very dissatisfied" and 5= "Very satisfied"). These were based 
on Hart and Hogg's (1998) service evaluation criteria scale developed for legal services (see appendix 2).

The third section of the questionnaire contained a number of scale items related to the emotional element of the service. This was measured using a 5 point Likert scale and asked respondents to "indicate to what extent you would feel the following' (5= "Not at all" and 1= "Extremely"). This was based on Richins (1997) Consumption Emotions Set (CES) but with the clusters of Loneliness, Romantic Love, Envy, Peacefulness and Love being removed as they were regarded as inappropriate during the piloting of the questionnaire (see appendix 3).

Overall satisfaction was measured using a single item 5-point Likert scale (e.g. Cronin and Taylor, 1992; Odekerken-Schroder et al, 2000) and asked respondents "How would you rate your overall satisfaction with the service you received" (1= "Very Satisfied" and $5=$ "Very Dissatisfied")

The final section of the questionnaire consisted of questions designed to collect classification data. The questionnaire was extensively pre-tested to ensure any items that may have caused difficulties to respondents were identified and modified. After making the required modifications, the questionnaire was administered. 


\section{KEY FINDINGS}

\section{Reliability and Validity}

A mean score of 4.14 for realism was achieved which suggests that the respondents perceived the scenarios to be highly realistic. The LPC mean was slightly higher than the NLPC mean at 4.15 against 4.13. An independent paired sample t-test was conducted to evaluate if there were significant differences between the LPC and NLPC groups in terms of their perception of the realism of the scenarios but this was not significant suggesting that both sets of students perceived the scenarios to be realistic.

An analysis of the responses revealed that a number of the LPC respondents (8) gave the incorrect answer or replied 'Don't Know' (7) to the question "Was the legal advice given correct?" . Analysis also revealed that a number of the NLPC responses (16) gave the correct answer to the same question. These responses were re-classified according to the respondents' knowledge of the technical attributes of the service encounter.

Independent sample t-tests were conducted to evaluate the effect of a manipulation in the relevant element of the service encounter (see appendix 4). As anticipated, the results largely showed statistically significant differences in the expected direction between group means on questions about satisfaction with the functional and emotional elements $(p<.05)$.

For the technical element of the service encounter (i.e. the legal advice), the t-tests were conducted within the LPC and NLPC groups. As anticipated, for the NLPC group there 
was no statistical difference in scores for technical satisfaction between the correct (positive) technical advice and the incorrect (negative) technical advice. For the LPC group, the results showed statistically significant differences in the expected direction between the group means for technical satisfaction for respondents receiving correct and incorrect legal advice. These results demonstrate that the NLPC group is unable to make performance assessments about the technical element of the service encounter but that the LPC group is.

\section{Factor Analysis}

The emotional component of the service encounter was subjected to a principal component factor analysis with a varimax rotation using SPSS. Prior to performing this the suitability of the data for factor analysis was assessed. Inspection of the correlation matrix revealed the presence of many coefficients of .3 and above. The Kaiser-MeyerOlkin (KMO) value was .877 exceeding the recommended value of .6 (Kaiser, 1970, 1974) and the Bartlett's Test of Sphericity (Bartlett, 1954) reached statistical significance, supporting the factorability of the correlation matrix. The analysis resulted in a two-factor solution accounting for $54.7 \%$ of the variance. All the items loaded significantly (minimum of .55 for a sample size of 100-120 according to Hair et al, 1995) except for 'Guilty' and this was removed from further analysis. With the items 'Frustrated', 'Calm', 'Irritated' and 'Amazed', there was a significant degree of cross loading and these items were also discarded from further analysis. The results are presented in Table 1. As anticipated, the results substantiate the existence of positive and negative emotional elements to the service encounter (Westbrook, 1987; Oliver, 1993) 
with the first factor being characterized by negative emotion $(29.62 \%$ of variance) and the second factor being characterized by positive emotion ( $29.14 \%$ of variance).

\begin{tabular}{|l|c|c|}
\hline \multicolumn{1}{|c|}{ Items } & $\begin{array}{c}\text { Factor 1: } \\
\text { Negative } \\
\text { Emotion }\end{array}$ & $\begin{array}{c}\text { Factor 2: } \\
\text { Positive } \\
\text { Emotion }\end{array}$ \\
\hline Sad & .805 & \\
\hline Nervous & .795 & \\
\hline Scared & .791 & \\
\hline Afraid & .786 & \\
\hline Panicky & .772 & \\
\hline Tense & .756 & \\
\hline Depressed & .737 & \\
\hline Miserable & .725 & \\
\hline Humiliated & .716 & \\
\hline Angry & .698 & \\
\hline Unfulfilled & .687 & \\
\hline Embarrassed & .686 & \\
\hline Surprised & .678 & \\
\hline Worried & .656 & \\
\hline Discontented & .642 & \\
\hline Ashamed & .626 & \\
\hline Astonished & .612 & \\
\hline Enthusiastic & & .882 \\
\hline Pleased & & .857 \\
\hline Encouraged & & .831 \\
\hline Happy & & .822 \\
\hline Relieved & & .822 \\
\hline Excited & & .814 \\
\hline Content & & .804 \\
\hline Joyful & & .792 \\
\hline Hopeful & & .775 \\
\hline Optimistic & & .736 \\
\hline Fulfilled & & .676 \\
\hline Proud & & \\
\hline Thrilled & & \\
\hline Eager & & \\
\hline & & \\
\hline
\end{tabular}

Table 1: Factor analysis results: Emotional component of service encounter 
The cognitive component of the service encounter was also subjected to a principal component factor analysis with a varimax rotation. Once again, prior to performing the analysis, the suitability of the data for factor analysis was assessed. Inspection of the correlation matrix revealed the presence of many coefficients of .3 and above. The KMO value on this occasion was .881 and the Bartlett's Test of Sphericity reached statistical significance.

The loading of these items was different to expectations as it was anticipated that the variables would load across the two factors of the functional and technical product. However, the factor analysis resulted in a three-factor solution accounting for $68.59 \%$ of the variance. All the items loaded significantly. With a number of items there was some cross loading but as their values were less than the 0.55 cut off (Hair et al, 1995) they were not seen as problematic. However, with other items there was significant cross loading. 'The degree of attention the partner gave your request' may be ambiguous in so far as it may be interpreted from a personal interaction perspective or from a technical perspective. Likewise, 'the importance attached to legal detail' and 'the reliability with which the partner dealt with your request' may also be interpreted from a technical or functional perspective. These items were removed from further analysis. The results are presented in Table 2 


\begin{tabular}{|l|c|c|c|}
\hline \multicolumn{1}{|c|}{ Items } & $\begin{array}{c}\text { Factor 1: } \\
\text { Interaction } \\
\text { Element }\end{array}$ & $\begin{array}{c}\text { Factor 2: } \\
\text { Technical } \\
\text { Element }\end{array}$ & $\begin{array}{c}\text { Factor 3: } \\
\text { Responsiveness } \\
\text { Element }\end{array}$ \\
\hline Degree of empathy & .867 & & \\
\hline Courtesy of partners and staff & .802 & & \\
\hline Degree of partner involvement & .726 & & \\
\hline Degree of reassurance and confidence & .694 & & \\
\hline Clear and understandable language & .637 & & .883 \\
\hline Legal knowledge of partner & & .837 & \\
\hline Quality of the legal advice given & & & .720 \\
\hline Commerciality of legal advice & & & .755 \\
\hline Promptness of the advice & & & \\
\hline Accessibility of partner & & & \\
\hline
\end{tabular}

Table 2: Factor analysis results: Cognitive components of service encounter

The results suggest that the cognitive component may not only comprise of a technical element (22.48\% of variance) but also suggests that the functional element may comprise of two further constituents. The first of these comprises of 'the degree of empathy with which the request was dealt', 'the courtesy of the partners and staff', 'the degree of partner involvement', 'the degree of reassurance and confidence with which the advice was given' and 'clear and understandable language' (27.47\% of the variance). These items relate to the nature of the interaction between the firm and the consumer and was labeled the 'interaction element'. The second of these comprised of 'the promptness of the advice given' and 'the accessibility of partner' (20.16\% of variance) and were related to the responsiveness of the partner and firm to the consumer and was labeled the 'responsiveness element'. This would appear to substantiate the findings of the exploratory interviews where responsiveness and timely accessibility to solicitors was identified as a key element of the service. As one respondent stated; "Its absolutely critical, both from their perspective [the law firm] and our perspective that we have 
accessibility [to the relevant solicitor] whenever we need it any time of the day or night.... and with the way mobile phones are nowadays, there really is no excuse" (Client of law firm).

The reliability of all the scales was established by utilising Cronbach's alpha. For the emotional component, negative emotion and positive emotion had alpha scores of .94 and .95 respectively. For the cognitive component, the interaction element, the technical element and the responsiveness element had scores of $.85, .80$ and .74 respectively. These values are above .7 so the scales can be considered reliable with this sample.

\section{Predictors of overall satisfaction}

Following the principal component analysis, standard multiple regression analysis was conducted to identify the variables that are most important in predicting overall satisfaction for the LPC and NLPC groups respectively. The independent variables were drawn from the dimensions produced in the factor analysis and consisted of positive emotion (reverse coded), negative emotion, interaction element, technical element and responsiveness element (see Table 3). 
LPC respondents

\begin{tabular}{|c|c|c|c|c|c|c|}
\hline $\begin{array}{l}\text { Dependent } \\
\text { Variable }\end{array}$ & $\begin{array}{l}\text { Independent } \\
\text { Variable }\end{array}$ & $\begin{array}{c}\text { Standardized } \\
\text { Coefficients } \\
(\beta)\end{array}$ & $\begin{array}{c}\mathrm{t}- \\
\text { value }\end{array}$ & VIF & Sig & Model $R^{2}$ \\
\hline $\begin{array}{c}\text { Overall } \\
\text { Satisfaction }\end{array}$ & $\begin{array}{c}\text { (Constant) } \\
\text { NE } \\
\text { PE } \\
\text { IE } \\
\text { TE } \\
\text { RE }\end{array}$ & $\begin{array}{l}-.124 \\
.194 \\
.475 \\
.267 \\
.293\end{array}$ & $\begin{array}{l}-1.824 \\
-1.136 \\
2.120 \\
3.813 \\
2.756 \\
2.906\end{array}$ & $\begin{array}{l}1.731 \\
1.220 \\
1.261 \\
1.359 \\
1.474\end{array}$ & $\begin{array}{l}.074 \\
.262 \\
.039 \\
.000 \\
.008 \\
.005\end{array}$ & .629 \\
\hline
\end{tabular}

NLPC respondents

\begin{tabular}{|c|c|c|c|c|c|c|}
\hline $\begin{array}{l}\text { Dependent } \\
\text { Variable }\end{array}$ & $\begin{array}{l}\text { Independent } \\
\text { Variable }\end{array}$ & $\begin{array}{c}\text { Standardized } \\
\text { Coefficients } \\
(\beta)\end{array}$ & $\begin{array}{c}\mathrm{t}- \\
\text { value }\end{array}$ & VIF & Sig & Model $R^{2}$ \\
\hline $\begin{array}{c}\text { Overall } \\
\text { Satisfaction }\end{array}$ & $\begin{array}{c}\text { (Constant) } \\
\text { NE } \\
\text { PE } \\
\text { IE } \\
\text { TE } \\
\text { RE }\end{array}$ & $\begin{array}{l}.083 \\
.166 \\
.369 \\
.243 \\
.158\end{array}$ & $\begin{array}{l}-1.978 \\
.912 \\
1.520 \\
2.697 \\
2.407 \\
1.476\end{array}$ & $\begin{array}{l}1.243 \\
1.801 \\
2.342 \\
1.542 \\
1.725\end{array}$ & $\begin{array}{l}.053 \\
.366 \\
.134 \\
.004 \\
.019 \\
.146\end{array}$ & .604 \\
\hline
\end{tabular}

Table 3: Regression Analysis with PE (Positive Emotion), NE (Negative Emotion), TE (Technical Element), IE (Interaction Element) and RE (Responsiveness Element)

For the LPC group, sixty three percent of the variance in overall satisfaction was explained by four variables. These are the cognitive components of the interaction element $(\beta=.475, p<.05)$, the responsiveness element $(\beta=.293, p<.05)$ and the technical element $(\beta=.267, p<.05)$ and positive emotion $(\beta=.194, p<.05)$. This would suggest that for the LPC group the cognitive components are the most important variables in determining overall satisfaction but with positive emotion also making a contribution.

For the NLPC group, sixty percent of the variance in overall satisfaction was explained by two variables. These are the interaction element $(\beta=.369, p<.05)$ and the technical 
element $(\beta=.243, p<.05)$. Thus, the responsive and emotional elements are not significant for this group but the technical element makes a significant contribution. This is contrary to expectations for two reasons;

- positive and negative emotions do not make a significant contribution in predicting satisfaction judgments for this group

- the manipulation tests conducted previously suggest that the NLPC is unable to make performance assessments about the technical attributes of the service encounter as they do not possess the necessary knowledge to do so.

A possible explanation for this is posited by Alford and Sherrell (1996). They suggest that where consumers are unable to evaluate the technical performance, they may rely on their emotional reaction to the service provider to derive performance judgments, thus implying that satisfaction with technical performance is a function of emotions evoked. In order to explore this further, a multiple regression analysis was performed with the variables that are most important in predicting satisfaction with the technical attributes of the service encounter for the LPC and NLPC groups respectively

\section{Predictors of satisfaction for the technical attributes}

The independent variables were again drawn from the dimensions produced in the factor analysis but with the dependent variable being satisfaction with the technical attributes of the service encounter (see Table 4). 
LPC respondents

\begin{tabular}{|c|c|c|c|c|c|c|}
\hline $\begin{array}{l}\text { Dependent } \\
\text { Variable }\end{array}$ & $\begin{array}{l}\text { Independent } \\
\text { Variable }\end{array}$ & $\begin{array}{c}\text { Standardized } \\
\text { Coefficients } \\
(\beta)\end{array}$ & $\begin{array}{c}\text { t- } \\
\text { value }\end{array}$ & VIF & Sig & Model $R^{2}$ \\
\hline $\begin{array}{c}\text { Technical } \\
\text { Satisfaction }\end{array}$ & $\begin{array}{c}\text { (Constant) } \\
\text { NE } \\
\text { PE } \\
\text { IE } \\
\text { RE }\end{array}$ & $\begin{array}{c}-.031 \\
-.280 \\
.267 \\
.344\end{array}$ & $\begin{array}{c}2.876 \\
-.191 \\
-2.191 \\
1.494 \\
2.474\end{array}$ & $\begin{array}{l}1.730 \\
1.113 \\
2.164 \\
1.313\end{array}$ & $\begin{array}{l}.006 \\
.849 \\
.033 \\
.141 \\
.017\end{array}$ & .206 \\
\hline
\end{tabular}

NLPC respondents

\begin{tabular}{|c|c|c|c|c|c|c|}
\hline $\begin{array}{l}\text { Dependent } \\
\text { Variable }\end{array}$ & $\begin{array}{l}\text { Independent } \\
\text { Variable }\end{array}$ & $\begin{array}{c}\text { Standardized } \\
\text { Coefficients } \\
(\beta)\end{array}$ & $\begin{array}{c}\mathrm{t}- \\
\text { value }\end{array}$ & VIF & Sig & Model $R^{2}$ \\
\hline $\begin{array}{c}\text { Technical } \\
\text { Satisfaction }\end{array}$ & $\begin{array}{c}\text { (Constant) } \\
\text { NE } \\
\text { PE } \\
\text { IE } \\
\text { RE }\end{array}$ & $\begin{array}{l}.040 \\
.354 \\
.165 \\
.160\end{array}$ & $\begin{array}{c}5.095 \\
.333 \\
2.599 \\
1.008 \\
1.148\end{array}$ & $\begin{array}{l}1.240 \\
1.607 \\
2.300 \\
1.686\end{array}$ & $\begin{array}{l}.000 \\
.740 \\
.012 \\
.318 \\
.256\end{array}$ & .305 \\
\hline
\end{tabular}

Table 4: Regression Analysis with PE (Positive Emotion), NE (Negative Emotion), IE (Interaction Element) and RE (Responsiveness Element)

The results suggest that there are differences in the way the two groups assess the technical attributes of the service encounter. For the LPC group, twenty percent of the variance in satisfaction with technical performance was explained by the two variables of the responsiveness element $(\beta=.344, p<.05)$ and positive emotion $(\beta=-280, p<.05)$. The negative relationship between positive emotion and technical satisfaction is ambiguous. One possible explanation for this emerged during the course of the exploratory interviews insofar as the legal advice proffered by the solicitor to a client may be technically correct but is not necessarily the outcome the client desired. As one solicitor stated; "You may have clients who will acknowledge that you have done a good job but will go away very 
disappointed with the result and think twice about coming back to you" (solicitor in medium sized law firm).

For the NLPC group, thirty percent of the variance in satisfaction with technical performance was explained by positive emotion $(\beta=.354, p<.05)$. This would appear to substantiate the findings of Alford and Sherrell (1996) insofar as provider emotion evoked through interaction at the service encounter may influence the perception of technical performance.

\section{DISCUSSION}

Proposition 1 appears to be partly substantiated. Where there is a higher level of consumer sophistication, the quality of the technical component makes a more significant contribution to overall satisfaction judgments than the emotional component. However, it does not make a more significant contribution than the interaction or responsive components of the functional product.

Proposition 2 is not substantiated insofar as the link between the emotional component and overall satisfaction is indirect. For unsophisticated consumers, technical satisfaction is a function of positive emotion evoked during the service encounter.

Thus, the degree of consumer sophistication appears to have a moderating influence in terms of the role and functionality of the technical and emotional component when making overall satisfaction judgments in a credence service context. This is also 
collaborated by the exploratory interviews. One respondent stated "[some clients] will go around the lawyers that are available until he finds a person he likes and feels comfortable with" (solicitor in medium sized law firm). These results appear to substantiate the findings of Alford and Sherrell (1996) insofar as where the consumer has difficulties in assessing performance, their emotional reaction to the service provider during the service encounter may affect performance evaluations of the technical element. Thus, in such circumstances, satisfaction with technical attributes of the service may be interpreted as being a function of emotion evoked during the service encounter. This is conceptually represented in Figure 3

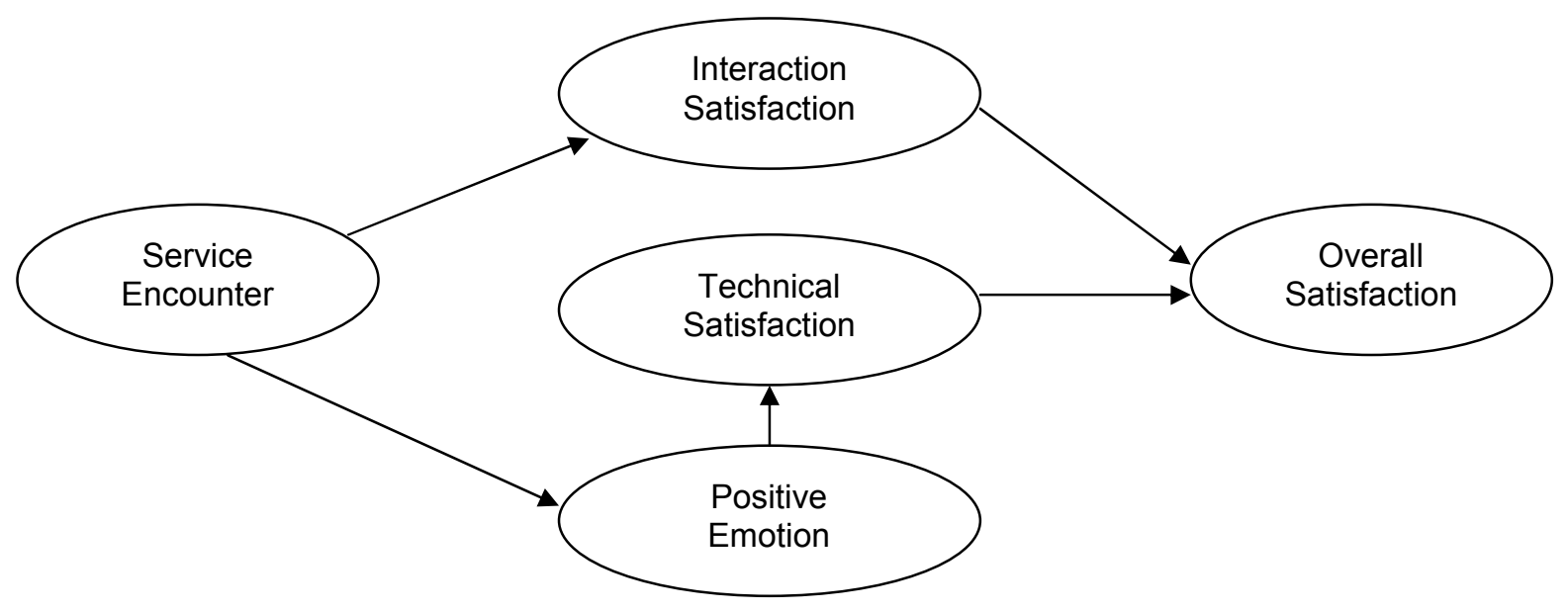

Figure 3: Proposed credence service satisfaction model for unsophisticated consumers

Where the consumer is able to form expectation and performance assessments and to understand the features and benefits of the product or service they are receiving, the 
relationship between emotion evoked and satisfaction appears to be more direct. This may be conceptually represented in Figure 4.

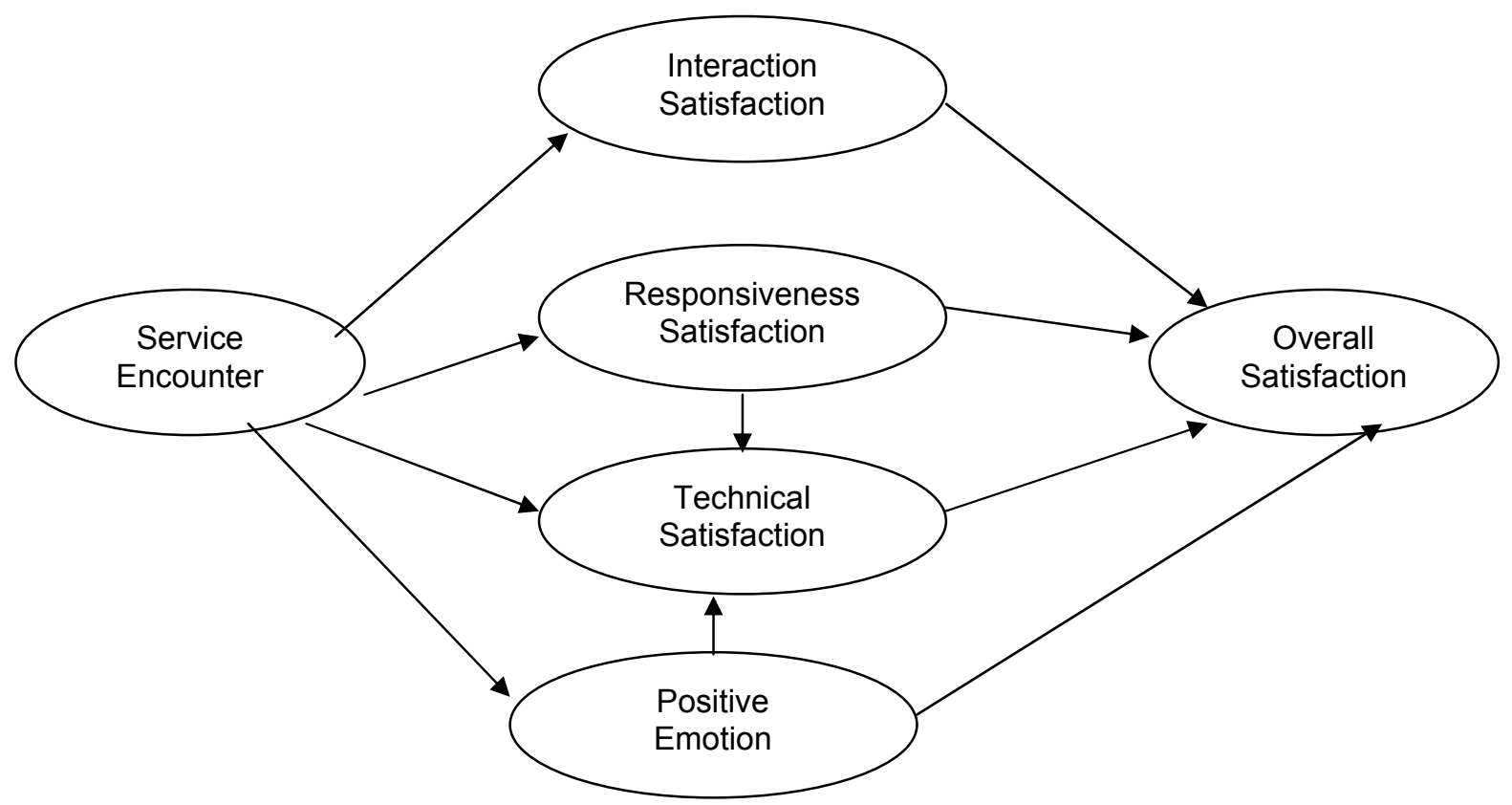

Figure 4: Proposed credence service satisfaction model for sophisticated consumers

Interestingly, negative emotion makes no contribution towards overall satisfaction judgments for either group of respondents. One possible explanation for this is that the purchase of legal services is, by its nature, often perceived to be a distress purchase. Respondents may therefore anticipate the evocation of negative emotions before and during interaction with the service provider and as a result, these do not detract from overall satisfaction judgments. In contrast, when the interaction is non-contentious, positive affect is evoked. 


\section{IMPLICATIONS AND CONCLUSIONS}

Emotion is a complex and vague dimension. Whilst emotion is evoked by the subjective appraisal of a stimulus, it is the individual's needs and coping potential that determine which emotions are evoked and to what extent (Nyer, 1997). Thus, the individuals' pertinent skills, knowledge, experience and possible technical qualifications may be a contributory factor in determining their emotional response to a service stimulus and their subsequent coping mechanism. This has important consequences for marketers as coping mechanisms used by individuals in a consumption context may include word of mouth recommendation, complaint behaviour and repurchase intention (e.g. Bagozzi et al, 1999). This would imply that credence service providers need to devote effort to devising appropriate service delivery processes that are pertinent to the individual consumer. This in turn has implications for the recruitment, training and empowerment of employees. Historically, credence service organizations have focused on technical qualifications together with experiential knowledge as the key drivers of HRM strategies such as recruitment and reward systems. However, this research suggests that satisfaction with the service and its provider may be assessed in a number of ways other than purely by reference to the technical attributes. Credence service providers need to recognize that every interaction with consumers is unique and that, critically, they need to be sensitive as to how the various elements of the service encounter may be assessed, how these may impact on overall satisfaction judgments and what the resultant coping mechanism may be. 
However, these results need to be interpreted cautiously. The sample comprised of students rather than actual consumers and a mental simulation may fail to capture all of the complexities and subtleties of real-world service delivery. For pragmatic reasons this research was designed in such a way that respondents either had the ability to form performance assessments of the technical element of the service encounter or they did not. The exploratory interviews conducted for this research suggests this is over simplistic. In reality, consumer sophistication should be viewed as a continuum ranging from those consumers that possess a high level of performance assessment abilities at one extreme through to those at the other extreme that possess relatively little or no performance assessment abilities. Further research is required into the relationship between customer sophistication, the assessments of the elements of the service encounter and their Affect on overall satisfaction based on this continuum. 


\section{REFERENCES}

Alford, B. and Sherrell, D., (1996), "The Role of Affect in Consumer Satisfaction Judgments of CredenceBased Services", Journal of Business Research, Vol. 37, pp71-84

Bagozzi, R., Gopinath, M. and Nyer, P., (1999), “The Role of Emotions in Marketing”, Journal of the Academy of Marketing Science, Vol. 27, No.2, pp. 184-206

Bryman, A., (1989) "Research Methods and Organisational Studies”, (Ed) Bulmer, M., Contemporary Social Research, London, Unwin Hyman

Burstin, K., Doughtie, E. and Raphaeli A., (1980) “Constructive vignette technique: An indirect methodology designed to address reactive social attitude measurement" Journal of Applied Social Psychology, Vol. 10, pp. 147-165

Cronin, J. and Taylor, S., (1992), "Measuring Service Quality: A Re-examination and Extension” Journal of Marketing Management, Vol. 56, July, pp. 55 - 68

Crosby, L.A. and Stevens, N., (1987), "Effects of Relationship Marketing on Relationship Satisfaction, Retention and Prices in the Life Insurance Industry", Journal of Marketing Research, Vol. 24, November, pp. 404 - 411.

Geertz, C., (1973), “The Interpretation of Cultures”, New York, Basic Books.

Hair, J., Anderson, R., Tatham, R. and Black, W. (1995), Multivariate Data Analysis Maxwell MacMillan International

Hanlon, G., (1997), " A Profession in Transition? - Lawyers, The Market and Significant Others", The Modern Law Review, November, Vol. 60, no. 6, pp. 798-822

Hart, S. and Hogg G., (1998), "Relationship Marketing in Corporate Legal Services" The Service Industries Journal, Vol. 18, No.3, pp. 55-69

Hartley, J. (1994), “Case Studies in Organisational Research” In: Cassell, C., Symon, G. (Eds) (1994). Qualitative Methods in Organisational Research: A Practical Guide, Sage, London pp. 208-226.

Homburg, C., Koschate, N. and Hoyer, D., (2006), “The Role of Cognition and Affect in the Formation of Customer Satisfaction: A Dynamic Perspective”, Journal of Marketing, Vol. 70, July, pp. 21-31

Johnson, A. and Stewart, D., (1996), “A Reappraisal of the Role of Emotion in Consumer Behaviour: Traditional and Contemporary Approaches", (Ed) Malhortra, N., Review of Marketing Research, M.E. Sharpe, New York

Landy, D. and Aronson, E. (1969), "The influence of the Character of the criminal and his victim on the decision of simulated jurors" Journal of Experimental Social Psychology, Vol. 5, pp.141-152

Mano, H. and Oliver, R.L. (1993), "Assessing the Dimensionality and Structure as Consumption Experience: Evaluation, Feeling and Satisfaction”, Journal of Consumer Research, 20: 451-466

Nosanchuk, T.A. , (1972), "The vignette as an experimental approach to the study of social status: An exploratory study", Social Science Research Vol. 1, pp. 107-120 
Nyer, .U; P. (1997), “A Study of the Relationships Between Cognitive Appraisals and Consumption Emotions", Journal of the Academy of Marketing Science, Vol. 25, No. 4, pp. 296-304

Oliver, R.L., (1993), “Cognitive, Affective and Attribute Basis of the Satisfaction Response”, Journal of Consumer Research, 20, pp 418-430

Randall, D. and Gibson, A., (1990), "Methodology in Business Ethics Research: A Review and Critical Assessment” Journal of Business Ethics, Vol. 6, pp. 383-391

Richins, M. (1997), "Measuring Emotions in the Consumption Experience", Journal of Consumer Research, Vol 24, pp 127-146.

Schoefer, K. and Ennew, C., (2005), "The Impact of Perceived Justice on Consumers' Emotional Responses to Service Complaint Experiences" Journal of Services Marketing, Vol. 19, No. 5, pp. 261-270.

Smith, A. and Bolton, R. (2002), "The Effect of Customers' Emotional Responses to Service Failures on their Recovery Effort Evaluation and Satisfaction Judgments", Journal of the Academy of Marketing Science, Vol. 30 No. 1, pp. 5-23

Van Maanen, J. (1979),

"The Fact of Fiction in Organisational Ethnography" Administrative Science Quarterly No. 24, pp 539-550, In Harris, L. (2002), "Developing Market Orientation: An Exploration of Differences in Management Approaches” Journal of Marketing Management Vol. 18, No 7-8, pp. 603-632

Weber (1992), "Scenarios in Business Ethics Research: Review, Critical Assessment and Recommendations", Business Ethics Quarterly, Vol. 2, Issue 3.

Westbrook, R.A. (1987), "Product/Consumption-Based Affective Responses and Post-purchase Processes", Journal of Marketing Research, 24, 258-270.

White, C. and Yu, Y., (2005), "Satisfaction Emotions and Consumer Behavioural Intentions", Journal of Service Marketing, Vol. 19, No. 6 


\section{APPENDIX 1 : MANIPULATIONS OF THE TECHNICAL, FUNCTIONAL AND AFFECTIVE ELEMENTS OF THE SERVICE ENCOUNTER}

\begin{tabular}{|c|c|}
\hline Technical Positive & Technical Negative \\
\hline $\begin{array}{l}\text { He explains that a distinctive trade mark will } \\
\text { distinguish the goods of one undertaking from } \\
\text { another. In other words, the application is weak as } \\
\text { it lacks the distinction required to achieve this and is } \\
\text { unlikely to be successful. He specifically cites the } \\
\text { case of Philips Electronics NV v Remington } \\
\text { Consumer Products Ltd (2002) All ER (EC) } 634 \\
\text { during his explanation. }\end{array}$ & $\begin{array}{l}\text { He specifically cites the case of Philips Electronics } \\
\text { NV v Remington Consumer Products Ltd (2002) } \\
\text { All ER (EC) } 634 \text { and explains how under similar } \\
\text { circumstances an application for trade mark } \\
\text { registration was successful. }\end{array}$ \\
\hline Functional Positive & Functional Negative \\
\hline $\begin{array}{l}\text { Sure enough, the solicitor rings you back within } 30 \\
\text { minutes and you explain the situation to him. }\end{array}$ & $\begin{array}{l}\text { However, you still have not heard back from the } \\
\text { solicitor by the following afternoon so you phone } \\
\text { again. This time you are put through and explain the } \\
\text { situation to him. }\end{array}$ \\
\hline $\begin{array}{l}\text { The correspondence arrives at your premises the } \\
\text { following day }\end{array}$ & $\begin{array}{l}\text { By the following week, the correspondence still has } \\
\text { not arrived so you phone up to chase it and are told } \\
\text { by the solicitor's secretary that she will look into it. }\end{array}$ \\
\hline Affect Positive & Affect Negative \\
\hline $\begin{array}{l}\text { The solicitor greets you warmly, listens carefully to } \\
\text { you and asks a number of questions. He tells you he } \\
\text { has a lot of experience in this area and given what } \\
\text { you have told him, the trade mark application is (un) } \\
\text { likely to succeed }\end{array}$ & $\begin{array}{l}\text { The solicitor listens to you and then curtly explains } \\
\text { that there is a good probability that the trade mark } \\
\text { would (not) be granted. }\end{array}$ \\
\hline $\begin{array}{l}\text { You continue to chat and it soon becomes apparent } \\
\text { that you know a lot of mutual acquaintances and } \\
\text { you proceed to exchange some humorous anecdotes } \\
\text { about one or two of them. The phone call concludes } \\
\text { with the solicitor assuring you that you have nothing } \\
\text { to worry about and that he will send a letter in the } \\
\text { next post summarizing his advice. }\end{array}$ & $\begin{array}{l}\text { When you attempt to ask him some questions he } \\
\text { says that from a legal perspective, that is all you } \\
\text { need to know and if you want any more information } \\
\text { than you will have to speak to his junior. There is a } \\
\text { long silence. The phone call concludes with the } \\
\text { solicitor informing you that he will send a } \\
\text { correspondence summarizing his advice together } \\
\text { with his invoice and he promptly hangs up. }\end{array}$ \\
\hline
\end{tabular}




\title{
APPENDIX 2 : SATISFACTION DIMENSIONS OF THE COGNITIVE COMPONENT OF THE SERVICE (BASED ON HART AND HOGG'S (1998) SERVICE EVALUATION CRITERIA FOR LEGAL SERVICES
}

\author{
Degree of empathy \\ Importance attached to legal detail \\ Courtesy of the partner and staff \\ Promptness of the advice \\ Degree of reassurance and confidence with which the advice was given \\ Accessibility of the partner \\ Legal knowledge of the partner \\ Commerciality of the legal advice \\ How clearly and in language that you understood the advice was given \\ Reliability of the partner \\ Degree of attention the partner appeared to give your request. \\ Reliability of the partner \\ Degree of partner involvement \\ Quality of the legal advice given
}

\section{APPENDIX 3: DIMENSIONS OF EMOTIONS EVOKED (BASED ON RICHINS (1997) CONSUMPTIONS SET (CES))}

Frustrated; Optimistic; Irritated; Calm; Amazed; Nervous; Surprised; Tense; Thrilled; Sad; Peaceful; Scared; Happy; Panicky; Encouraged; Contented; Humiliated; Joyful; Afraid; Enthusiastic; Depressed; Guilty; Relieved; Hopeful; Worried; Pleased; Angry; Excited; Miserable; Eager; Embarrassed; Fulfilled; Astonished; Discontented; Proud; Unfulfilled; Ashamed. 


\section{APPENDIX 4: INDEPENDENT SAMPLE T-TESTS FOR THE MANIPULATION OF THE ELEMENTS OF THE SERVICE ENCOUNTER}

Independent Sample t-test for the Manipulation of the Functional Element of the Service

\begin{tabular}{|l|c|c|c|}
\hline \multicolumn{1}{|c|}{ Item } & $\begin{array}{c}\text { Positive Outcome } \\
\text { Mean Score }\end{array}$ & $\begin{array}{c}\text { Negative Outcome } \\
\text { Mean Score }\end{array}$ & $\begin{array}{c}\text { Sig. of t } \\
\text { (2-tailed) }\end{array}$ \\
\hline Empathy & 3.19 & 2.88 & .156 \\
\hline Courtesy & 3.37 & 2.62 & .001 \\
\hline Promptness & 4.0 & 2.48 & .000 \\
\hline Accessibility & 3.68 & 2.34 & .000 \\
\hline Reassurance and confidence & 3.59 & 3.01 & .003 \\
\hline Clear and understandable language & 3.53 & 3.36 & .336 \\
\hline Reliability & 3.47 & 2.59 & .000 \\
\hline Attention & 3.14 & 2.45 & .001 \\
\hline Partner involvement & 3.22 & 2.69 & .006 \\
\hline
\end{tabular}

Independent Sample t-test for the Manipulation of the Affective Element of the Service

\begin{tabular}{|c|c|c|c|}
\hline Item & $\begin{array}{c}\text { Positive Outcome } \\
\text { Mean Score }\end{array}$ & $\begin{array}{c}\text { Negative Outcome } \\
\text { Mean Score }\end{array}$ & $\begin{array}{c}\text { Sig. of t } \\
\text { (2-tailed) }\end{array}$ \\
\hline Frustrated & 3.71 & 2.79 & .000 \\
\hline Optimistic & 3.33 & 3.80 & .039 \\
\hline Irritated & 3.57 & 2.79 & .001 \\
\hline Calm & 3.10 & 3.91 & .000 \\
\hline Amazed & 4.10 & 3.5 & .029 \\
\hline Nervous & 4.07 & 3.59 & .029 \\
\hline Surprised & 3.74 & 3.27 & .007 \\
\hline Tense & 3.79 & 3.20 & .211 \\
\hline Thrilled & 4.22 & 4.48 & .001 \\
\hline Sad & 4.41 & 3.66 & .003 \\
\hline Peaceful & 4.00 & 4.55 & .112 \\
\hline Scared & 4.36 & 4.04 & \\
\hline
\end{tabular}




\begin{tabular}{|c|c|c|c|}
\hline Happy & 3.78 & 4.32 & .014 \\
\hline Panicky & 4.22 & 3.81 & .052 \\
\hline Encouraged & 3.63 & 4.24 & .003 \\
\hline Content & 3.67 & 4.16 & .015 \\
\hline Humiliated & 4.69 & 3.73 & .000 \\
\hline Joyful & 4.29 & 4.75 & .008 \\
\hline Afraid & 4.46 & 4.09 & .058 \\
\hline Enthusiastic & 3.86 & 4.52 & .001 \\
\hline Depressed & 4.38 & 3.91 & .023 \\
\hline Guilty & 4.81 & 4.65 & .252 \\
\hline Relieved & 3.86 & 4.33 & .022 \\
\hline Hopeful & 3.38 & 3.91 & .011 \\
\hline Worried & 3.47 & 3.41 & .777 \\
\hline Pleased & 3.78 & 4.40 & .002 \\
\hline Angry & 4.12 & 3.15 & .000 \\
\hline Excited & 4.15 & 4.53 & .053 \\
\hline Miserable & 4.42 & 3.98 & .022 \\
\hline Eager & 3.52 & 4.40 & .000 \\
\hline Embarrassed & 4.68 & 4.31 & .025 \\
\hline Fulfilled & 4.00 & 4.65 & .000 \\
\hline Astonished & 4.10 & 3.47 & .008 \\
\hline Discontented & 3.78 & 2.90 & .000 \\
\hline Proud & 4.41 & 4.66 & .132 \\
\hline Unfulfilled & 3.76 & 2.88 & .000 \\
\hline Ashamed & 4.69 & 4.34 & .053 \\
\hline
\end{tabular}

Independent Sample t-test for the Manipulation of the Technical Element of the Service for the NLPC Group

\begin{tabular}{|l|c|c|c|}
\hline \multicolumn{1}{|c|}{ Item } & $\begin{array}{c}\text { Positive Outcome } \\
\text { (Correct Advice) } \\
\text { Mean Score }\end{array}$ & $\begin{array}{c}\text { Negative Outcome } \\
\text { (Incorrect Advice) } \\
\text { Mean Score }\end{array}$ & $\begin{array}{c}\text { Sig. of t } \\
\text { (2-tailed) }\end{array}$ \\
\hline Legal detail & 3.07 & 3.09 & .964 \\
\hline Legal knowledge & 3.00 & 3.3 & .123 \\
\hline Commerciality of advice & 3.00 & 2.94 & .785 \\
\hline Quality of advice & 2.93 & 3.03 & .645 \\
\hline
\end{tabular}


Independent Sample t-test for the Manipulation of the Technical Element of the Service for the LPC Group

\begin{tabular}{|l|c|c|c|}
\hline \multicolumn{1}{|c|}{ Item } & $\begin{array}{c}\text { Positive Outcome } \\
\text { (Correct Advice) } \\
\text { Mean Score }\end{array}$ & $\begin{array}{c}\text { Negative Outcome } \\
\text { (Incorrect Advice) } \\
\text { Mean Score }\end{array}$ & $\begin{array}{c}\text { Sig. of t } \\
\text { (2-tailed) }\end{array}$ \\
\hline Legal detail & 3.48 & 2.29 & .000 \\
\hline Legal knowledge & 3.83 & 2.38 & .000 \\
\hline Commerciality of advice & 3.42 & 2.33 & 000 \\
\hline Quality of advice & 3.58 & 1.96 & .000 \\
\hline
\end{tabular}

